edge and extension at the trailing edge.

Alvarez leads us to this hypothesis along a personal and scientific journey through many scientific, historical and cultural byways. The book reads like an extended field guide and notebook - Alvarez mingles the story of his involvement with Italian geologists with accounts of his travels, discoveries and what might be called an Italian history of the world, in which various historical figures receive proper credit for thinking of things first. Many of them, such as the seventeenth-century Danish geologist Nicolaus Steno, need no introduction to geological readers. But some Italian figures will be unfamiliar, such as the 'father of Italian geology' Giovanni Arduino, who gave us the now obsolete term 'tertiary' in the eighteenth century.

Alvarez obsesses a little about issues of priority, recalling my feeling that his other book was uncomfortably full of praise for those collaborators who had set their competing claims aside. Here, too, using many historical examples, Alvarez shows the reader how well scientists behave when science works.

I particularly relished the moral he draws from how alpine thrust faults were correctly explained. These faults are flat planes along which huge masses of rock have travelled horizontally, often for hundreds of kilometres. After years of doubt, geologists finally accepted that rocks could be pushed such large distances - their acceptance of plate tectonics sapped all controversy from the issue. Alvarez uses this to remind us of a phenomenon first identified by astronomers Alan Lightman and Owen Gingerich in 1992, whereby well-established ruling theories "develop a life of their own" and seem to take forever to collapse under the weight of conflicting evidence.

There is an irony here because the connection that Alvarez and others made between the iridium anomaly and the Chicxulub crater has become just such a ruling theory in recent years, one that sceptical scientists have challenged at their peril. One must conclude that the book was already with the publishers last year when Gerta Keller, a professor at Princeton University in New Jersey, persuasively debunked Chicxulub as $T$. rex's crater of doom by proving it was 300,000 years too old. Alvarez's frequent references to the crater as the uncontested 'smoking gun' would otherwise, presumably, have been phrased more circumspectly.

Like Alvarez's previous book, The Mountains of St Francis is a first-person participant history. This genre carries dangers, not least the pitfall of overplaying the author's centrality. Alvarez is given to grand gesture, and sometimes allows himself to come too close to writing what Stephen Jay Gould dubbed "cardboard history". For example, he avers that, by the 1930s, Alfred Wegener's ideas on continental drift had been "mostly rejected". True, Wegener's fellow geophysicists rejected his hypothesis because they thought it was physically impossible. But, as science historian Naomi Oreskes has shown, it was only in the United States - for a long time a bastion of old-fashioned continental fixism - that geologists rejected drift en masse. Elsewhere they remained more open-minded.

Alvarez deserves his place in posterity. Along with others, including my late professor, Derek Ager, he has helped geologists to understand that uniformitarianism and gradualism are not the same thing. On the timescale of a planet, uniformity must also embrace rare, catastrophic events that may recur on timescales far beyond the duration of civilizations and even species.

Whatever the truth behind his sometimes overconfident side-statements about the endCretaceous extinction, meteorite impacts, the iridium anomaly, Chicxulub crater and science history, the tectonic story running through this book is compelling and engagingly told. It also holds appeal for lay readers, perhaps less so than his previous book, but those who venture into the mountains of St Francis with Alvarez will not regret it. I would make it required background reading for students of Earth science. It would certainly help counteract the occasional philistinism of those leading their field trips. Ted Nield is editor of Geoscientist magazine and author of Supercontinent.

e-mail: ted.nield@geolsoc.org.uk

\title{
Stalin's war on genetic science
}

\section{The Murder of Nikolai Vavilov: The Story of Stalin's Persecution of One of the Great Scientists of the Twentieth Century by Peter Pringle Simon and Schuster: 2008. 384 pp. $\$ 26$}

It is not surprising, given the parlous state of Russia in the years following the Revolution, that its political system put ideology and practical outcomes above all else, including scientific fact. This was most evident in agriculture, where it was imperative to produce more food by whatever means. The consequences were tragic for the Russian people and for Nikolai Ivanovich Vavilov, Russia's greatest geneticist. Vavilov fell foul of Trofim Denisovich Lysenko who, through political manipulation and intrigue, came to dominate Soviet genetics.Peter Pringle's compelling book, The Murder of Nikolai Vavilov, tells the story of the Lysenko affair with verve and pace. Pringle makes it clear how Vavilov's patriotism, dedication to science and determination to be open-minded led to his downfall and death.

Vavilov was born in 1887 in Moscow into a comfortable, bourgeois family. In 1906 he entered the Petrovskaya Agriculture Academy, or Petrovska, one of many institutes established after the devastating famine of 1892. Russian agricultural practices lagged behind those of other European countries and the United States, and efforts to reform them were unsuccessful. Vavilov undertook "to work for the benefit of the poor, the enslaved class of my country, to raise their level of knowledge". This pledge, Pringle explains, drove Vavilov throughout his life.

After graduating, Vavilov spent a year researching wheat with Robert Regel at the Bureau of Applied Botany in St Petersburg,

\section{To Follow the Water: Exploring the Ocean to Discover Climate}

by Dallas Murphy (Basic Books, $\$ 15.95$, E9.99)

As well as covering the history of human

expansion across the globe and the science of oceanography, Murphy also gives first-hand accounts of life on a research vessel. "Meticulously following the waters of the Gulf Stream into the blue beyond, Murphy's book gets it right," wrote Arnold Gordon (Nature 449, 407-408; 2007).

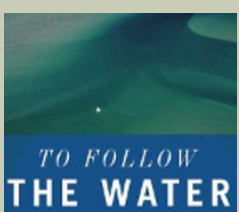

Brussels Versus the Beltway: Advocacy in the United States and the European Union by Christine Mahoney (Georgetown Univ. Press, \$29.95)

Political decisions made in Washington DC and Brussels have global effects, but US and European advocacy styles are often assumed to be culturally different. This book challenges stereotypes, arguing that the context of issues and institutions is more important than differences between cultures.

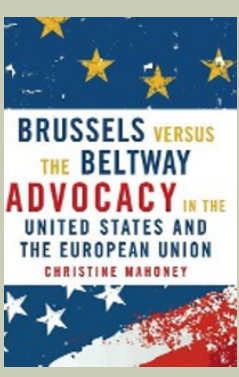


before embarking on a two-year tour of European laboratories. His stay with William Bateson in Cambridge, UK, was the highlight. Bateson was the leading proponent of Gregor Mendel's work on inherited traits, rediscovered 10 years earlier, and wrote the first genetics textbook, Mendel's Principles of Heredity, published in 1909. Bateson's enthusiasm for Mendelian genetics seems to have rubbed off: Vavilov based his life's work on Mendelian principles and their elaboration by, among others, fly geneticist Thomas Hunt Morgan. Bateson had led an expedition to the Russian Steppes in 1886 to examine the interactions of environment and species variability. Pringle suggests that this may have inspired Vavilov to undertake similar expeditions to search for crop varieties whose traits made them suitable for particular environments, such as dry or cold regions.

On Vavilov's return to Russia and the Petrovska, he was sent to investigate why soldiers on the Persian front were falling ill after eating bread. Vavilov used the assignment to collect varieties of plants growing in the harsh climate of the Pamir mountains, in the hope that these hardy plants might be cultivated in northern Russia to provide more food for the Soviet people. Vavilov endured great hardship in travelling to such remote regions, trips that would now be unthinkable without insulated jackets, mobile phones and satellite navigation.

Vavilov returned from the Pamirs in 1916 to find Russia in political turmoil. In March 1917, Tsar Nicholas II abdicated and by October, the Bolsheviks had seized the reins of government, plunging the country into civil war. Nevertheless, Vavilov's career began auspiciously - he took up a full professorship at the University of Saratov, a large city on the Volga river some 700 kilometres southeast of Moscow. Vavilov mounted expeditions to Afghanistan, Ethiopia, Eritrea, North and South America and the Mediterranean, seeking plants that might increase agricultural productivity in Russia. He regarded this as an essential task after the disastrous collapse of Soviet agriculture that followed the consolidation of land and labour known as collectivization that began around 1929. Vavilov's

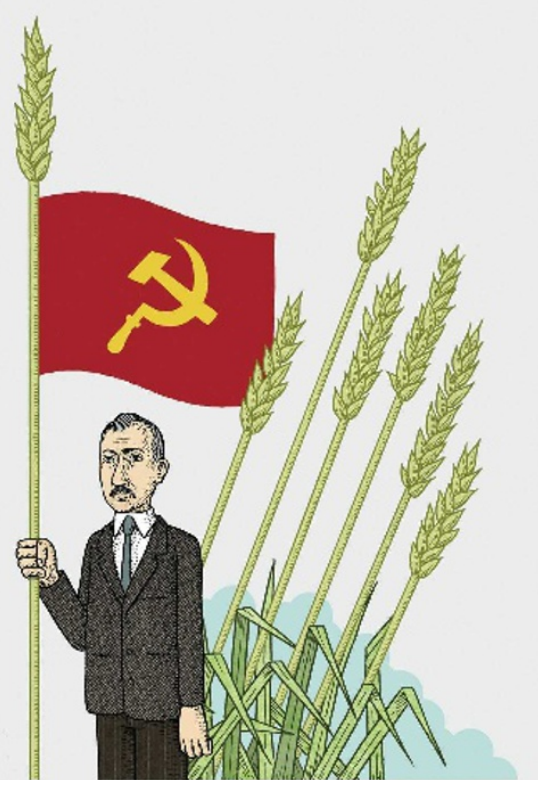

collection of 250,000 seeds of cultivated plants and their varieties was the most extensive in the world. In 1930, he was appointed director of the Institute of Genetics of the USSR Academy of Sciences in recognition of his position as the country's leading plant geneticist and his international reputation. Just six years later, Vavilov was in disgrace.

His nemesis Lysenko was born in 1898 into a peasant family. Unusually for the time, he attended a school of agriculture and horticulture; clever and ambitious, he aspired to make great contributions to Soviet science. His big break as an agricultural researcher came in 1927, when the newspaper Pravda reported his work on changing the time of sprouting in seeds by exposing them to differing periods of cold temperatures, known as vernalization. The reporter noted that Lysenko was working for the people, not carrying out research for its own sake by studying the "hairy legs of flies". Lysenko promoted himself as the discoverer of vernalization, although it had been known since 1858 , and trumpeted it as a solution to the Soviet Union's chronic food shortages.

Lysenko claimed that plants could be 'educated' so that the changed germination time became heritable after several generations of vernalization. This was a variant of Lamarckism, or the inheritance of acquired characters, that had been discredited first by August Weismann's distinction between germ cells and somatic cells, and second by Mendel's work. Scientists rejected Lysenko's claims, but by skilful manipulation of the political situation throughout his career, Lysenko scaled the Soviet scientific hierarchy. He was twice awarded the Order of Lenin, and became president of the Lenin Academy of Agricultural Sciences of the USSR, a full member of the country's Academy of Sciences and a member of the Supreme Soviet.

The conflict between Lysenko and the 'Mendelian-Morganists' came to a head in 1936 at a conference at the Lenin Academy. Despite geneticists' devastating scientific critique of Lysenko's claims, the government-controlled press declared Lysenko the winner. Attacks on Vavilov's position increased and Lysenko consolidated his position. Senior scientists in the Soviet administration were among the victims of Stalin's Great Purge, when perhaps as many as one million anti-revolutionaries and enemies of the people were executed over two years, including Muralov, president of the Lenin Academy. Lysenko took his place to become Vavilov's boss. In October 1939, the Central Committee of the Communist Party of the Soviet Union held another genetics conference. This again ended in triumph for Lysenko.

Why were the reins of Soviet agriculture held by a charlatan whose policies were disastrous? As Pringle makes clear, Lysenko prospered because he promised rapid advances in agriculture that were seized on by a Soviet government desperate to feed thousands of citizens dying of starvation. Lysenko promised Stalin that new strains of wheat and other crops with desirable traits could be produced within 3 years, much quicker than the 12 years that Vavilov required. Perhaps as importantly, Lysenko's views of genetics were in sympathy with prevailing Marxist dogma.

Experts, by virtue of their education and role, were members of the bourgeoisie and regarded with suspicion in Russia. There was a strong political movement to replace the intelligentsia with elevated peasants and other members of the proletariat, even if they were untrained and ill-fitted to their new posts. Lysenko was one such example. Vavilov, by contrast, was an educated, well-travelled businessman's son who was

\section{Genes in Conflict: The Biology of Selfish \\ Genetic Elements}

by Austin Burt and Robert Trivers

(Harvard Univ. Press, \$24.95, £16.95)

The book examines how selfish genes thrive despite damaging their carrier. Burt and Trivers describe how such genes spread through populations by distorting transmission on a molecular level and increasing their own replication, or by changing how an organism treats its kin.

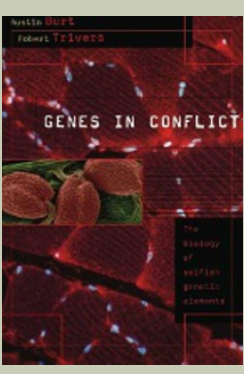

A Guinea Pig's History of Biology: The Plants and Animals Who Taught Us the Facts of Life by Jim Endersby (Arrow, £8.99)

From Mendel's peas to modern laboratories, Endersby's entertaining book explores the history of science through the plants and animals that provided answers or, often, more questions. Covering the familiar ground of mice and fruitflies, the book also highlights organisms that led scientists up the wrong path, such as the zebra-like quagga.

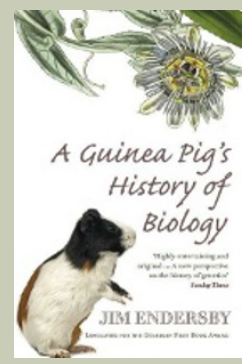


thought to be susceptible to foreign influences.

And why did Vavilov not fight Lysenko earlier and more aggressively? Pringle demonstrates that Vavilov was guided by his student pledge to help the Soviet people and that he was committed to exploring all leads, however improbable, that might increase food production. Vavilov encouraged many scientists, including Lysenko, to test different approaches. Naively, Vavilov did not expect that Lysenko would play by political rather than scientific rules. At a 1948 session of the Lenin Academy, Stalin was so determined that Lysenko should triumph that he drafted Lysenko's opening remarks himself, emphasizing the correctness of Lamarckian thinking. A letter included in the official report ended: "Glory to the great Stalin ... coryphaeus of progressive science!"

Neither Vavilov nor his work featured in this session. Following the 1939 conference, Lysenko had progressively dismantled Vavilov's institute, but Vavilov had remained free even as criticism of him became ever more vituperative. Then, on 6 August 1940, while collecting plants in the Ukraine, Vavilov was seized by the Soviet secret police and taken to Moscow. Pringle's account of Vavilov's 11-month interrogation is horrifying. In July 1941, Vavilov and two colleagues were tried and sentenced to death. Vavilov's appeal to the Presidium of the Supreme Soviet was turned down, but a personal plea to the head of the secret police led to his sentence being commuted to life imprisonment. His colleagues were shot. Vavilov died of starvation on 26 January 1943 in a prison in Saratov, the city where he had begun his illustrious career 26 years before.

Even now, politics continues to trump good science, as is evident from the delays in reducing global carbon emissions. Pringle's very readable account is a timely reminder that public policies must be based on rational decisions drawn from the best data available.

Jan Witkowski is executive director of the Banbury Center and professor in the Watson School of Biological Sciences at Cold Spring Harbor Laboratory, New York 11724, USA. He is co-author of Recombinant DNA: Genes and Genomes. e-mail:witkowsk@cshl.edu

\section{Betting on black holes}

\author{
The Black Hole War: My Battle with Stephen \\ Hawking to Make the World Safe for \\ Quantum Mechanics \\ by Leonard Susskind \\ Little Brown: 2008. 416 pp. \$27.99
}

The idea of a black hole in space produced by the collapse of a massive star dates back to the 1930 s, but it was only in the 1960s that astrophysicists began to understand the details. Evidence now suggests that black holes do exist, and are a key element of the great cosmic story. Yet some of their predicted properties remain puzzling and threaten cherished physical laws.

One long-running conflict concerns the fate of the material that implodes to form a black hole. In his new book The Black Hole War, theoretical physicist Leonard Susskind of Stanford University, California, describes how he sparred with Stephen Hawking of the University of

Cambridge, UK, about this thorny issue.

Black holes earn their name because their gravity is so strong they trap even light, appearing black from the outside. According to Einstein's general theory of relativity, the ball of matter that implodes to create the hole continues to shrink, meeting an uncertain fate at the centre and leaving behind it a region of empty space. Because physicists believe nothing can go faster than light, no information or material should escape the hole. Practically all the information about the collapsed star would be lost from the outside Universe, making it impossible to tell whether the star was made of matter, antimatter or green cheese; once inside the hole, its external physical properties would be the same.

A twist arose in 1975 when Hawking argued that black holes are not perfectly black. By applying quantum mechanics to the formation process of a black hole, he predicted that it must radiate heat. Because heat is a form of energy, this radiance would have to be paid for by gradually reducing the hole's mass, because energy and mass are equivalent in general relativity. In time, the hole would evaporate away completely, leaving behind just heat energy, mostly in the form of photons, with a few other particles such as neutrinos and electrons.

On an immense timescale, vastly longer than the current age of the Universe, the black hole would convert the entire star into heat. Hawking concluded that the heat energy would look the same whatever the star was made of originally. Many physicists did not like this conclusion. A principle of quantum mechanics is that information is never created or destroyed in a quantum process. For example, if you throw an encyclopaedia into a furnace, it might seem that the information is irretrievably lost, turned into incoherent heat. According to quantum mechanics, however, the information is lost only for practical purposes. The infrared photons emitted by the embers still contain the original information, but in a hopelessly scrambled form that renders it inaccessible to us. Leading particle physicists, led mainly by Susskind and Gerard 't Hooft of the University of Utrecht in the Netherlands, declared that the same would be true of black holes - the information about the original star would be enfolded in the emitted heat. It might be jumbled up, but it should all be there.

Hawking begged to differ. I recall him going through the argument during a conversation in

\section{Endless Universe: Beyond the Big Bang - Rewriting Cosmic History}

by Paul J. Steinhardt and Neil Turok (Broadway, \$14.95, £8.99)

Two theoretical physicists challenge the widely accepted Big Bang Theory. Turok and Steinhardt explain how new developments in astronomy, cosmology and physics have led them to develop their own 'Cyclical Universe' theory to explain cosmic origins.

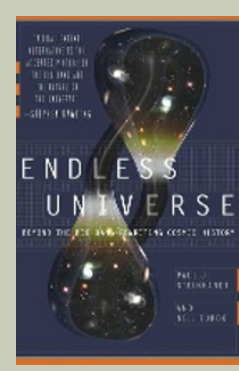

The Beginner's Guide to Winning The Nobel Prize: A Life in Science

by Peter Doherty (Columbia Univ. Press, E10.95)

Doherty's highly readable book describes how

to succeed in science and hopefully win that coveted prize. "For the aspiring young scientist, or a student considering a scientific career, Doherty opens the vault to the world of science, explaining how it works and how to get on," according to Peter Parham's review (Nature 443, 755-756; 2006).

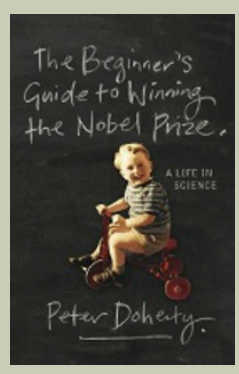

